\title{
A Scientific Critique of Evolution...The Need For An Alternative (to what is now believed)
}

\author{
Samuel A. Nigro ${ }^{1}$
}

1. M.D., Retired Assistant Clinical Professor of Psychiatry Case Western Reserve University

\author{
ARTICLE INFO \\ Corresponding Author: \\ Samuel A. Nigro \\ M.D., Retired Assistant Clinical \\ Professor of Psychiatry Case \\ Western Reserve University.
}

\begin{abstract}
Everyone has bought into current evolution theories by dogmatic acceptance without usual scientific criticism. No alternative is offered but the scientific criticisms should be respectfully accepted and answered.
\end{abstract}

\section{INTRODUCTION}

This article provides 19 scientific criticisms of evolution: (1) the negative impact; (2) similarity infers but does not prove developmental relationship; (3) creatures are stable;

(4) the time available for mutational changes is suspect;

(5) the compensation requirements for negative and neutral mutational changes overwhelm "natural selection;" (6) pheromones are biological objections to evolution; (7) creatures have a difference tolerance incompatible with major changes; (8) self-reorganization is never seen; (9) personal experience with positive chemical changes remain with the individual and are not passed on; (10) complex protein creation is extremely improbable de novo; (11) the Principle of Uncertainty cannot be overcome; (12) Godel's Theorems of Undecidability and Incompleteness mitigate against it; (13) the species based "struggle for life" is patently untrue; (14) there is a "neurotheologycenter" in the human brain and Stephen Hawking's eight basic physics principles can be identified as metaphorically spiritual; (15) ideas are not accounted for; (16) scientists' psychological needs account for most of Darwin's acceptability and promotion; (17) a culture of masturbation is outside of planetary nature and the related norms of abortion and contraception are totally against evolution and natural selection; (18) pseudo-scientific gurus present arguments of faith and ignore newly evolved metaphors of science which are consistent with old metaphors of religion (The data used in this article have no doubt changed but never enough to alter conclusions offered); (19) the required complexity for "life" on the planet as we observe it scientifically render the probability for duplication to be impossible.
The 1859 publication of Darwin's Origin of Specieshas led to the dogmatic acceptance of evolution and natural selection to explain life in the universe (Of interest is the full censorship of the embarrassing title of the book, which is On the Origin of Species by Means of Natural Selection or the Preservation of Favoured Races in the Struggle for Life). However, evolution has never really been scientifically criticized, which is definitely not how real science operates. It is difficult to find any other formulation not allowed genuine scientific criticism.

This article offers, in an honest academic effort, real critical thinking and criticisms of Darwin as appropriate and should be honestly promulgated and discussed. Failure to do so is to betray science i.e., most scientific hypotheses and theories are challenged vigorously and usually modified or even refuted about every five years. One must be skeptical of scientific theories that cannot be challenged. Indeed, all science flip- 
flops, or maybe it "evolves"...except intransigent

Darwinism (as it contradicts itself and dogmatizes science?).

To read The Origin... is to be astonished at the lack of real science, the absence of anything approaching what could pass for real scientific proof, and the presence of one anecdote after another pulled together by perseverating theory and drawing lines. Darwin made an argument ("As this volume is one long argument (emphasis added)..." page 384) of great appeal and verbosity often using the word "imaginary" (pages 66 \& 71 for examples), but he never scientifically proved anything. Indeed, Darwin seems initially reluctant about extending evolution beyond "species" cosmetology until his enthusiastic impressionable disciples promoted it as "fact" for all life, until he felt comfortable with it. (Then, Darwin, following his enthusiasts, reminds of the French Revolution man who was asked why was he running after the mob...and he said, "I have to chase them...I am their leader.").

Regardless, genuine proof is rare if at all for all evolutionists ever since-but they make arguments and you damn well better believe them. Regardless, "origin of species" is one thing, while "origin of genera and phyla" are another, never proven and wisely omitted from the title, but always taken for granted and spread like miasma by his disciples.

My background is one of firm belief in Darwin for most of my life as a Roman Catholic psychiatrist proud that the Parisian clerics of the 13th Century gave rise to contemporary science. However, in the past decade, I began to look closer and doubts arose. To say that finches' beaks changed was one thing, but all the rest became fraught with pompous wishful leaps of thinking, lack of real evidence, no real "proofs", and huge improbabilities for anything but changing of species. Indeed, promulgation of anecdotes, yes; testing, no. Thus I became agnostic about Darwin and published my findings in an article ("Why Evolutionary Theories Are Unbelievable," Social Justice Review, Jan.-Feb 2004, pages 148-151). The following points, some in the article, are respectfully offered as critical challenges to Darwin except as a dated celebrity:

1. Doubt about Darwin's ideas exists because of their negative impact on

humanity. Undeniable is the dehumanization resultant from Darwin. In America, in actual fact and not in the fabricated movie or fanciful play, the Scopes Trial featured Clarence Darrow, without embarrassment, defending the evolutionary based superiority of Caucasians to Negroes (and everybody else) in the prohibited biology textbook's presentation of evolution (No doubt helping reinforce eugenics and the hierarchy of races leading to:

"Segregation then. Segregation now.Segregation forever."). From the prohibited textbook of the Scopes Trial, George William Hunter's ACivic Biology (1914):

The Races of Man. - At the present time there exist upon the earth

five races or varieties of man, each very different from the others

in instincts, social customs, and, to an extent, in structure. These are the Ethiopian or negro type, originating in Africa; the Malay or brown race, from the islands of the Pacific; the American Indian; the Mongolian or yellow race, including the natives of China,

Japan and the Eskimos; and finally, the highest of all, inhabitants of Europe and America (page 196).

The preceding is what the Scopes trial defended and really sums up the negatives of Darwinism: It began as intolerant 
racist notes about the natives on Tierra del Fuego and is ending up anti-Catholic, anti-Christian, anti-religion, and anti-human. The Ku Klux Klan, the Nazis, South African apartheid, and Planned Parenthood began with, or were at least affirmed by and rooted in, Darwin, as is anything else which "improves" your "population" at the expense of others.

Second, and notable, is the negative impact wherein the "war with all" Darwinian mantra of nature was implemented:

...if we did not respect
the law of nature,
imposing our will by the
right of the stronger, the
day would come when
the wild animals would
again devour us-then
the insects would eat the
wild animals, and finally
nothing would exist
except the microbes. By
means of the struggle,
the elites are continually
renewed. The law of
selection justifies this
incessant struggle by
allowing the survival of
the fittest.

Thus spoke Adolf Hitler, who echoed Hunter's prohibited book in the Scopes Trial:

The Remedy. - If such people [add: the "unfit"] were lower animals, we would probably kill them off to prevent them from spreading.

Humanity will not allow this [add: until Hitler], but we do have the remedy

of separating the sexes in asylums or other places and in various ways

preventing intermarriage and the possibilities of perpetuating such

a low and degenerate race. Remedies of this sort have been tried

successfully in Europe and are now meeting with some success in

this country [add: Margaret Sanger and Planned Parenthood].

So Hitler and others like him, thanks to Charles Darwin and Clarence Darrow, misunderstand the symphony of life and promote the grisly morning-after of Darwin: Fight, kill, survive, every creature for itself getting all it can for itself and for its population by getting rid of those decreed unfit (Recent tendentious efforts have been made to sanitize Darwin, but such is too little too late to undo the Hitlerian press and media imposed "law of selection" mindlessly obeyed by manipulated and suggestible citizens even today)!

Finally, the negative impact of Darwin's ideas must include "abortion as a medical procedure." Paradoxically, abortion is both an extreme implementation of Darwinism's “kill if you can get away with it as selected for yourself and your population's benefit;" and at the same time, abortion is an absolutely bizarre contradiction to self-evolving and the promotion of oneself and one's population as required by Darwinism. Somehow, someway, if you believe in evolution, you have to be against abortion (and contraception!), or else, with unrecognized negative impact, you are lying to yourself.

2. Doubt about Darwin's ideas exists about the obvious requirement that similarity is relationship and even identity. To claim there is an identity or developmental linkage because of the presence of common construction material or common/similarities in design, is a pleasing scientific leap but without real proof (In fact, Darwin unscientifically claims that even common "instincts" or "habits" are confirming of his theory, page 222).

For opposing examples, all creatures using oxygen are not identical; nor are those using water; nor are those preferring the use of two legs; nor are those comprised of amino acids; nor are those with genes. Indeed that someone in California habitually uses the same type cell 
phone which I use does not mean that we have a meaningful identifiable developmental originating relationship.

Similarity without identity is explained by the fact that there are common building blocks for all creatures: amino acids. That amino acids comprise life proves no more identity relationship for different creatures than different buildings are related if both are built in part with Italian marble. Similarity is not identity even if the building blocks are essentially the same in composition. Man's genes are 99\% in common with some chimpanzees; $75 \%$ in common with the dog and grey wolf; $40 \%$ in common with the banana; and has some 200 genes in common with bacteria. The most one can reasonably say is that there is common construction, common material, common design, and perhaps even common function. But there is no proof of developmental identity. The teeth of a shark are no more developmentally related to your teeth than to the teeth of a chain saw, even if a neat dogmatic line is drawn between them.

3. Doubt about Darwin's ideas exists because of the stability of creatures. Significant changes do occur within creatures when regulatory genes and molecules are teased by events affecting creatures. This is well demonstrated by study of bacteria and other microorganisms as well as finch beaks. An illuminating example is the intense interbreeding of dogs as occurred over several thousand generations during 130,000 years resulting in today's approximately 34 species and 150 breeds of dogs. But not to be overlooked is that any dog is still a dog, genetically identical to the grey wolf. Even with the significant changes due to regulatory genes and molecular alterations in microorganisms, finches or dogs, the organism is still the same organism and there is no hint of major change in terms of new genera or phyla or even interchanges between microorganisms to finches to dogs and vice versa. Cosmetic changes are not the same as major developmental genus/phylum recombinations into new markedly different creatures.

Overall, to extrapolate natural adjustments to natural modifications under appropriate natural situations, whether random or by manipulation (although there is no "natural" manipulation), and call it "natural selection or preservation of favored races" implying that nature can select and leap to create new creatures beyond the intrinsic original creature itself leading to the alleged "phylogenetic tree of life" is more fantasy than proven. There is no reasonable evidence for genus/phylum leaps (and Darwin knew itreread the self-limiting, to a point, title of his book!

4. Doubt about Darwin's ideas exists because of the time available in which an idealized "natural selection" has allegedly created identifiable major changes and adjustments resulting in a new genus and the "phylogenetic tree."

Much can be learned from viral, bacteriologic, and immunologic studies and from studies of unicellular creatures, all of which are often touted as examples of evolution in action proving that new phylogenetic creatures are possible. However, studies reveal mutation rates inadequate for the creation of complex animals. An "evolving" generation of 20 years for humans does not compare well with a generation rate of 20 minutes for bacteria. For example, a trillion bacteria need 65,000 generations (or 4 years) for a two amino acid mutation. Extrapolated to other creatures, as Darwinists do over and 
over, about 1.3 million generations of humans are needed for a comparable two amino acid chemical mutation in a population of a trillion people. Sequential positive mutational evolution into the 3.5 billion base pairs of human DNA would require $4.6 \times 10^{15}$ (4.6 million billion) years, and the universe is said to be 15 billion years old. So how many years does it take for positive mutations to get a finch? A horse?A cow?Any creature? And all these creations ongoingin myriad different mutational directions at the same time? I could buy it only as part of the Big Bang Statimuum moment, but not as evolution in space-time continuum.

So let us speed up the process and not use a bacterial generation rate of 20 minutes extrapolated. Instead assume all creatures have developed from simple molecules over 3.5 billion years (As first living creatures, bacteria are said to be 3.5 billion years old). To get to us humans with 3.5 billion base pairs now requires 1 pair of amino acid positive mutations compounded uninterruptedly each year for 3.5 billion years (with automatic pass through implementation and acceptance by all the subgene proteins, without fail, able to follow the new gene's directions). Or, if humans began development 2 million years ago as believed and the first homo sapiens is thought to have arrived 50,000 years ago, then 2,333 positive mutations each year are needed for the 750,000 twenty year human generations (with an impossible sequentially mutated offspring each year, in those 20 years of reproduction) during the 1.5 million years to get to us today with 3.5 billion human base pairs also sequentially automatically without fail working together positively. It is actually more difficult because the demographics are relatively low: An estimated 5 million (5 one hundred thousandth of a trillion) humans lived in 8000 B.C. and the total number of humans ever born is about 106 billion by 2006, numbers far below the trillions of bacteria from which much mutational data are obtained. All this is magnified by almost $18 \%$ since recent evolutionists claim that human ancestors branched from bacteria 2 billion years ago instead of the accepted 3.5 billion years, so there is even less time for all human evolution. It does not add up, and will not with any updating of numbers, which will occur because science always changes (except Darwinism).

The mutational needs are mind boggling: After bacteria 3.5 billion years ago, animals left the ocean 375 million years ago. Mammal lineage left the reptiles between 200 and 250 million years ago. The common ancestor of humans, cows, whales, and bats was a small mammal (no doubt without 3.5 billion base pairs) about 100 million years ago. The first primates were 60-80 million years ago. The last common ancestors for all monkeys and apes were 40 million years ago. The common ancestors for humans and chimps were 6-7 million years ago. The earliest known fossil of a modern human is less than 200,000 years ago. It may have happened, but not by the mutation rates and generation rates--not for today's 3.5 billion human base pairs or for the trillions of base pairs of other animals. To believe otherwise is unscientific.

5. Doubt about Darwin's ideas exists because of the compensation requirements for the one hundred negative/neutral mutations occurring relative to 1 positive mutation. Given the profound aimlessness and lack of direct design (except for the fanciful "selection by nature") required by Darwinism, all the cumulative attributes of positive mutations must also be said about the harmful- 
negative mutations which are not immediately lethal. Thus, positive complexification, even if geometrically or sexually compounded, will be delayed by a factor equal to the rate of geometrically or sexually compounded negative mutations. Or else each negative mutation must be offset by a countering positive mutation, but each of these offsetting positive mutations will also have with it another at least 10 harmful and 90 neutral ones. That is, if there are at least 10 negative mutations, as generally accepted, for each positive one, the creation of complex amino acid creatures from the first single amino acid creatures does not add up. And if there are at least 90 neutral mutations, as generally accepted, going nowhere for each positive one, positive complexification will be delayed by a factor of 100 for each two amino acid changes or equivalent needed for each creature's advance in evolution. So the odds are 100 nowhere-or-worse to 1 advancement for mutational changes. "Natural selection" has to be pretty smart to beat 100 to 1 odds. This is science?

Considered in light of the needed 2,333 positive mutations yearly (for 1.5 million years) supra, there will be 23,330 negative and 209,970 neutral ones each year. And if mutations were so frequent as required, why did the copious mutation process stop? Spare me.

Sexual interaction and compounding seems to be further confounded if not precluded because close inbreeding and creation of hybrids almost always results in sterile offspring (Darwin wrote about that in chapter IX with the defensive admonition that such was "not acquired by natural selection"-Right: How about "natural obstruction."). Regardless, creatures cannot reproduce well if they differ more than a little from their genetic basis and partner's genetic identity-or the routine is that the partner had the same positive mutation at the same time?

6. Doubt about Darwin's ideas exist because of pheromones. The very same biology used to allegedly "prove" evolution disproves it moreso. This has to do with the planetary ecology of sex: Essentially, all sexuality and mating for all subhuman animalsis pheromone dependentand consistent with reproduction. Pheromones, biochemical errors accepted, confine copulation to mature opposite sexed creatures of the same species at a time consistent with reproduction.

Indeed, humans are the only creatures not pheromone dependent for mating. Humans are free from pheromone control and thus even in sexuality can humans pollute by rejecting Nature and natural function--just as with almost everything else humans do (It must have something to do with original sin). Humans pay little attention to Nature until a real mess is created. Without pheromone control, humans do not have Nature's standards for animals and are therefore indiscriminate and anti-ecological in sexual activity alleging "freedom" when, of course, it is merely that humans can again choose against nature and even use the reproductive system for something other than its natural purpose of reproduction (It is amazing that the only organization still promoting sex as reproductive is the Roman Catholic Church).

Without pheromone control, humans become seduced by glitzy degrading sex-as-recreation contrary to natural function, thusly polluting the planet even in biological behavior perhaps appropriately called "sexcretion" because it sure is not reproduction as for the rest of the animal kingdom and Nature. Indeed, if we forced animals to treat sex like we do, it would be animal 
cruelty and against the law. For humans, sex outside of reproduction and unition in marriage is actually nothing but excretion-accurately called "mutual toileting" and "sexcretion."

Without a doubt, this overlooked pheromone independence of humans has been projected onto the animal kingdom thus resulting in the theory of evolution, because evolution as currently conceived is only possible if subhuman animals do not have pheromones. $A u$ fond,evolution is a psychotic interpretation andprojection of human pheromone independence onto the animal kingdom. It is psychotic because pheromone independence for subhuman animals is a delusion. One will never find or see subhuman animals in sexual activity or mating that is not with a like animal having matching pheromones, although infrequently subhuman animals also have mental illnesses and idiosyncratic events.

Homosexuals and gay cultists have exaggerated all non-mating animal idiosyncrasies and illnesses, especially in 2 books: Biological Exuberance: Animal Homosexuality and Natural Diversity by Bruce Bagemihl and Evolution's Rainbow: Diversity, Gender, and Sexuality in Nature and People by Joan Roughgarden-Neither book lists "pheromone" in the index, and it is obvious that the authors likely never heard of pheromones rendering both books to be unscientific propaganda, because it is fraud to discuss animal sexuality without consideration of pheromones (Reviews of both books are available from me). Incontrovertibly, pheromones mean that mating (sexual activity) is reproduction consistent activity with a mature opposite sex member of the same species. PERIOD.
In terms of "evolution," pheromones mean there will not be mating of different species, and thus there are no natural hybrids in nature. There can be genetic adaptive alterations in a species as described by Darwin, but there are no major cross species mating or "miscegnation" (for want of a better word). If the pheromones do not match, there will be no mating! Thus the whole large genetic interplay and multiple gene transferring required by evolution for major speciescreation and change is a fantasy because different species do not mate and there will be no hybrids in Nature.

In addition, from what we know about forced hybridization done by human manipulation of fairly similar species (to mules or tigrons, for examples), the resulting created hybrid animalscannot reproduce, likely because of non-matching meiosis, and there goes evolution down the drain again. Thus, even if there were natural hybrids, science shows they cannot reproduce! It is a fantasy that cross-breeding results in "new" greatly changed species.

So there you have it: In nature, there is no mating without pheromone matching; there are no animal hybrids in nature; and artificially created animal hybrids are sterile and cannot reproduce. These are scientific facts. Thus, there is no major species changing evolution as dogmatically demanded, and it is unscientific to believe init. Tell your friends!

It is worth repeating that Religion can live with evolution or without it. In fact, religion lays claim to ecological soundness by the "psychosocial pheromones" from the Roman Catholic Church-the only organization in the world promoting human sex consistent with Natural 
Law and Transcendental Love (The psychosocial pheromone from the Church is known as the Sacrament of "Matrimony.").

In contrast, however, atheists cannot livewithout evolution ...which is science fiction and a myth as currently promoted. For biologists, evolutionists, and atheists, their problem is real science which they must ignore.

7. Doubt about Darwin's ideas also exists when one considers the difference tolerance of living creatures. For example, humans have 30,000 genes (maybe twice that according to some). About $1 / 3$ rd of human gene functions are known. Another 1/3rd of human genes have non-human homologues found in other creatures. And 1/3rd of human gene's functions are not known. All genes are comprised of four bases of adenine, taurine, guanine and cytosine. All creatures are composed of proteins of these four bases and another 16 amino acids. The human genome contains 3.5 billion base pairs of DNA; and about one in a thousand base pairs are different between humans while the rest are identical. Thus there is a very limited polymorphism within human biological beingness of about three million different bases in DNA for human organisms (if 30,000 genes) while the remaining $3,497,000,000$ base pairs maintain the creature. Obviously the human creature can tolerate one in a thousand differences without major loss while changes over and above that involve illness, loss of function or other negative effects including death. It seems that the difference tolerance has been maximized and stabilized for human beings and all creatures. That is, genes determine and preserve a creature within certain limits. One is justified to think such is the case for all stable creatures because that is all we find: stable creatures with limited species modification potential that we have to unnaturally cultivate to obtain! In other words, to break away from the stable mold into a really new different creature, genus or phylum begs belief, because the "evolving" creature cannot live that long, if at all, with a major change exceeding its defined difference tolerance, which is not very much considering all that is there. And, not to be forgotten in considering low difference tolerance, is that close inbreeding and cross breeding results in sterility of offspring and thus there is no further evolution whatever difference occurred.

It is hard to deny that each creature is a symphony, not a bored chaos trying to climb out of itself. The interaction among the proteins is stabilized such that the creature remains alive and viable in communion with the universe at the level which the stable complex of amino acids allow. To look at the totality of a complex creature or any creature, is to be astonished that it is there at all and that it does not fall apart easily. It is undeniable that once amino acid creatures become stabilized, they like it that way. The stability of the limited and low frequency polymorphism of creatures renders improbable any major new changes worthy of the alleged phylogenetic tree or even "meaningful major new functions." This seems to be "natural obstruction" rather than "natural selection". Clearly, the more mutations, the less likely reproduction.

8. Doubt exists about Darwin's ideas of selfintegration and self-creation because there is absolutely no evidence of such self-reorganization where it ought to be. Why cannot life be recreated for the molecules and other cells if they are supposed to be able to "naturally select" by themselves? If you break up a few cells, they do not 
reconstitute back into the cell -- which should be easier

after breaking up than relying on a random accumulation of molecules as was supposed to have originally happened!

Don't they ever learn? What, no spontaneous algorithmic process? No cumulative embryonic process? If the creature put itself together once upon a time, then it must be able to do it again, especially if the molecules are already there. Or, more likely: Only retrospective evolution works wherein the target states are known in advance... but that is not evolution or science properly defined but cute anecdotes, a myriad of which were provided by Darwin as he followed his loquacious faithfilled true believers. And natural healing is not an adequate answer, because it is a process of duplication or replacement rather than actual creation or re-creation.

9. Doubt exists about Darwin's ideas on the basis of personal experience. As a physician, I alter the chemistry of my patients day in and day out. I see no evidence of "natural selection or the preservation of favored races" for the next generation eagerly proceeding from my induced positive chemical changes, and I have seen a lot of 20 year plus generations. In medicine, all we really see is the opposite of positive "natural selection or preservation of favored races." And, quite frankly, good habits have to be relearned every generation; they are not "naturally selected". Really, where is this "natural selection or preservation of favored races" when you need it? I mean, how dumb can "natural selection or preservation of favored races" be? All physicians would say the same if they thought about it. Today, physicians flood creatures with chemical alterations and we try to train people galore; and where are the stabilizing selections, the recombining and accumulated offspring enhancement? There is no "natural selection or preservation of favored races" by the positive impacts of medications, but, au contraire, negative outcomes are readily incorporated, i.e., the disaster of thalidomide is a glaring example of genetic toxic selection, rather than "improving" as demanded by Darwin. To tamper with the basic intrinsic chemistry of amino acids is usually bad awful. There are environmental negative mutagens, but no environmental positive mutagens, try as we may, such that if something good happens, it seems never to be embraced for the next generation. Where is this natural selection and descent with modification providing a positive change actually seen in real life? Has anyone ever seen it? In fact, these negative acquisition phenomena of genetic toxicology are a total contradiction to "natural selection;" such is proof of "negative selection" and "negative accumulation," both also applicable to the "compensation needs" of 5 supra.

So I asked a veterinarian...who, after a moment of thinking, said: "After 5 generations of surgery because of ingested string, the owner had me sterilize all her cats. They never learn anything." And where was "natural selection or preservation of favored races"?

And a final query: If "natural selection or preservation of favored races" is supposed to be so good, why has breast cancer spread so markedly over the past few decades? And the increase in autism, attention deficit disorder, learning disabilities, and gender disturbances? Where is this always good selective accumulation and "natural selection or preservation of favored races" that supposedly got us here? There is no evidence or personal experiences of peoples getting healthier and improving by natural selection. Why do we, undeniably, only see the 
opposite? Experience shows that "natural selection or preservation of favored races" beyond cosmetology is really nothing but wishful thinking. The closest I have ever seen to "natural selection or preservation of favored races" with so-called positive outcomes are the Astrology Horoscopes and the creation of loud rhetorical public relations savvy atheist gurus (Read Feet of Clay by Anthony Storr).

10. Doubt about Darwin's ideas also exists in terms of the initial creation of complexprotein molecules outside of the cell. For example, the great British scientist Bernard Lavelle has stated:

A small protein molecule of 100 amino acid residues would require some ten to the 130th power trial assemblies to obtain the correct sequence. The probability of achieving this within a billion years is effectively zero.

The creation of thousands of protein chains in and out of cells into specific functioning and other stable reproducing creatures appears overwhelmingly improbable. Think of 3.5 billion base pairs per human. Think of any major protein molecule in any creature's body-insulin has 51 amino acids, hemoglobin 574, and myosin 6100.

And another scientist, Walter T. Brown, Jr. has written:

Laboratory synthesized amino acids always form in equal amounts of mirrorimage structures termed "left handed" and "right handed". Amino acids that comprise the proteins found in living things, including plants, animals, bacteria, moles and even viruses, are essentially all left handed. The mathematical probability that chance processes can produce just one tiny protein molecule with only left handed amino acids is virtually zero.

Of course, some have tried to dismiss this by commenting to effect that "mirror images do not have equal probabilities of binding to surfaces," which, because the right handed half of all proteins are typically useless, reduces by half the probabilities of accumulated complexification of all proteins into units with improved functional reproductive capabilities.

11. Like all scientists, Darwin has problems with the Principle of Uncertainty. Basically the principle says, "If you know how fast you are going, you do not know where you are; and if you know where you are, you do not know how fast you are going." It has to do with quantum mechanical ("mechanical/quantum" is better) states: particles/waves, position/momentum, location/frequency, and matter/form (or material/spirit). In a more practical sense, this means that as you study something and tease it apart and get to a certain point, you are altering it in such a way that you cannot really be certain as to what you are discovering. Thus, one ends up with "probability" and quantum physics with a potential intrinsic awareness of freedom best called "spirit" or maybe "soul" (You have to think about that, but it is true!). Regardless, materialist reduction creates artificiality which is not necessarily the reality, and if it is the reality, you cannot know it with perpetual certainty. In addition, further confounding is the fact that "fate is determined by observation," which is the subatomic particle equivalent to self-understanding, i.e. Only by an accurate philosophical understanding of material, formal, efficient and final causes determined by non-biological spirit can the Principle of Uncertainty be overcome. I call this extreme evolution. (A practical example of the Principle of Uncertainty is press-media content versus reality.)

12. Doubt is created about Darwin because of Godel's Theorems of Undecidabilityand Incompleteness (which are naggingly reminiscent of the 
principle of uncertainty, mechnical/quantum or matter/form, et cetera). Godel's Theorems apply to the most spiritual formalities of the human mind's mathematical potential i.e., formal mathematics.

Godel's First Theorem states that in a system of complexity, questions exist that are neither provable nor disprovable on the basis of the axioms in the system, i.e., that true statements are undecidable even if known to be true because they cannot be decided as true on the bases (matter) from the system itself. But because we understand this, an independent rational deciding intellect (our own...and maybe God?) outside the system is obvious.

Godel's Second Theorem is that any complex system is always incomplete because new undecidable elements (form) will always be present such that contradictions occur when the system claims it has decided all; that is, the system will generate more undecidability. But because we choose and still decide what to do outside the system, insightful complete free will (our own!) is obvious.

Godel's Theorems apply to every system of complexity and have been called, not entirely inappropriately, the mathematical proof of Original Sin. Thus, the universe and man is on a treadmill of undecidability (of matter) and incompleteness (of form), i.e., physical and mental entropy (known at the spirit level as "suffering" i.e. pain and sin) which probability-wise include Darwin's ideas (Godel himself called materialism “a prejudice of our time," and Darwin was not excluded). And yet, we can, as outside the system, if intellectually willed, see and participate in the anti-entropic ascendancy of matter-spirit composites in spite of undecidability and incompleteness by perhaps, a little touch of Natural Law rather than the laws of extreme science and the jungle. (Once again, a practical example of Godel's Theorems is press-media content versus reality, just as with the Principle of Uncertainty.)

13. Doubt exists about the Darwinian "struggle for life." This is not to deny the individual struggle for survival. However, there is no evidence of total species demanded ascendancy, except for a few arrogant humans. Clearly, increasing food and amino acids at a certain point typically leads to less reproduction and not more. There is no observed striving to always increase to the utmost at all times for any species. There is no "competition to the finish" as a total global rule--Most animals relax completely after a good meal. Individuals of most species, especially humans, try to work together, unless hungry. Indeed, in nature, the symphonic Christian-like working together is obvious in spite of entropic loss necessary for the conservation of energy and acquisition of food. There is not the fight to the death as Darwin requires for all creatures and their populations beyond basic living. There is neither "survival of" nor "reproduction of" the "fittest" whatever "fittest" means! Indeed, the harmony and symphony of life as a totum on the planet is amazing and the basis for all environmentalism. For most rational creatures, the accurate understanding of life is itself a contradiction of Darwin. In general, amino acid creatures are not at war with life. They just want to transcendentally live free and die free at their own matter/form levels in concert with nature, which means a "full stomach" for most

14. Doubt is created about Darwin when one discovers that there is a neurotheologycenter in the 
brain and that Stephen Hawking's eight physics principles of existence can be spiritual metaphors.

The neurotheologycenter in the brain is said to be the posterior superior parietal lobe, i.e., read the book Why God Won't Go Away, by Newberg, D'Aquili and Rause. This center is identified as related to meditation, reflection, and "mind on mind," "conscious of consciousness," "awareness of being aware," or, what I prefer, "C2" (consciousness squared). That there is a biological medium for spiritual functioning would not be surprising, and such provides the biological basis for the logical reflecting on God and that there is more than matter. It is certainly not consistent with "survival of the fittest" but "survival of the most spiritual...the most transcendental!" By this theology selfreflection center, man escapes from biological confinement to real freedom -- the human freedom to do and act on that which is not biologically confined. Complexification gives humanization and spiritualization, a material-spiritual winding up in a material matrix of winding down (There is salutary entropy—most commonly known as “sacrifice.").

There are eight physical variables in the continuum of space time according to Stephen Hawking in A Brief History of Time: event, spectrum, field, quantum, singularity, dimension, uncertainty and force..Amazingly, they metaphorically coincide with the transcendental variables of being, matter, identity, truth, oneness, good and beauty and with the community universals of dignity, unity, integrity, identity, spirituality, life, liberty, and pursuit of happiness. (All are made cogently clear in my books Everybody For Everybody and Soul of the Earth and in MedCrave Journal of Psycology and Clinical Psychiatryarticle "Make That Interaction Count" 2015,
2(3):00072.) For science to deny spirit is intellectual idiocy.

15. Doubt about Darwin's ideas exists because ideas themselves exist only in man thus proving supernaturei.e., escape from and control of biology at one extreme and angels ("Angels" are best understood scientifically as "words") trying to return to God at the other. Ideas and their significance cannot be denied. Taken for granted because everybody has them, ideas get no respect. But this must change because ideas confer spirit even if denied by scientists blinded by the Big Bang so they cannot see the pre-BigBang "Statimuum" usually called "Eternity."

Ideas are materially based in and a product of the brain which not only has consciousness but consciousness of consciousness $\left(\mathbf{C}^{2}\right)$ not present in subhumans. Without $\mathrm{C}^{2}$ and its rational capacity for ideas, nature must be followed as is the case for all subhuman creatures. In contrast, by ideas, humans have a rational intellect and free will to be above nature. By $\mathrm{C}^{2}$, ideas reverberate in the human mind with their being of spirit. To reflect deeply on ideas is to muddle around and conclude that ideas are bewilderingly pure spirit with a life of their own by words. Again, there is no evidence of $\mathrm{C}^{2}$ being found in subhumans and its presence is best recognized by the uniquely human "birthday" celebrations.

The reality of an idea forces the recognition of an incorporeal existence neither physical nor measurable by mathematics. Ideas prove a different dimension of existence. In fact,

ideasmake you what you are. That is: You are what you think! Such is the spirit of life; and, logically consistent with spirit, in the long run you will get what you think and do! That is, in the spirit world, that which one allows 
by rational intellect and free will in one's mind is that which one is and will become (...and will get!).

Ideas are God-like images within you. In my books, Happy Ending, Everybody for Everybody, and Soul of the Earth,, I propose that words are angels, i.e. spirit conveying messengers ranging from elementary objects of matter to the transcendentals. By angelic words, ideas are made real as God-like linkages in the spirit world. Thus the spirit world spreads from the most simplistic inanimate object to the mental world and the Divine...from simple numbers to angels to The Word. Supernatural spiritual transition occurs with the appearance of word created ideas such as "love," "person," the transcendentals, the virtues as well as other lesser ideas all of which individually and collectively prove a different level of existence and a different level of reality. The spirit existence is there. To deny spirit is to deny ideas; is to deny that words exist; is to deny the impact of words in the world of ideas; and is to deny a spirit world wherein anti-being demons (un- or antitranscendental words) try to run amuck while angels (transcendentally intact words) promote being.

The significance of ideas cannot be underestimated: You are your ideas-which can be non-being (Needless to remind, the promotion of non-being is evil). But the opposite is true: Your ideas can make you the best full being filled with truth, oneness, good and beauty in a confluence of transcendental existence into the level of spirit. Your ideas make you what you are. And what goes around, comes around. Your intellect and free will make it that way, and the ideas you put into action will determine your eternal spirit existence-In other words, you will get what you do over and over in Heaven, Purgatory or hell (simple ancient language-limited metaphors for the
preBigBang Eternity) i.e. In your spirit life, what you have been and done will come back to you in a caricature of your life by justice mirroring it all as well deserved! (Dante has it right!)

Ideas are Fire Forms from the Big Bang mediated by words (angels), transcendentalized (refired) by The Word (Jesus) which overcomes matter to return being to God. No matter how exciting or stimulating, if your ideas are not transcendental (true, one, good and beautiful), to hell with them because that is where they will take you. The transcendentals (Truth, Oneness, Good and Beauty) are the basis for and essence of all subjectivity by which concepts are warmed with the Image of God. The transcendentals are spirit computations ("strings") between you and the universe. And "The universe is the entropy necessary for Love" (another scientific metaphor consistent with ancient parables).

And Darwinians have not got the faintest idea of what I am writing, and will thusly fail the major personal and only "evolution" that matters. Regardless, the idea discontinuity between man and subhuman animals makes Darwin's ideas irrelevant and doubtful. Real "evolution" is spiritual more than biological.

16. Doubt about Darwin's ideas exists because of the transparently evident psychological needs of scientists who are greatly comforted and self-inflated by the selfish anti-authority aura of "evolution" as well as the pleasure of certainty when in compliance with elementary peer pressure. The unscientific untouchability of Darwin's Creed (not theories but "arguments" as he himself called them) enables scientists to sleep secure that materialism is the only "ism" in which they have to believe. Nevertheless, 
when scientists proclaim and protect arguments (nee' science) as dogmas, they stand Galileo on his head.

Aha: Perhaps the primary purpose of "evolution" is to allow atheists to sound off (by reporting, not testing; by promoting, not measuring; by arguing, not proving) in prejudiced imitation of the "fundamentalists" they claim to refute. Darwinians seem not to defend evolution with scientific confirmations or consistency but with antireligious arguments and propaganda as if religion is the only alternative to evolution, when they can be, within limits, hand and glove. Darwinism is a valiant effort to understand life without God, but when such occurs, science creates tendentious purposes beyond itself, and therefore is no longer pure science but a pretense that molecules have the answer for everything.

The psychological problems and immorality of Darwinists and atheists were paradigmatically well documented when University of Oxford's Richard Dawkins and Case Western Reserve University's Lawrence Krauss both stated in Scientific American (July 2007) that "education is seduction" (Look up the common definition of "seduction." Enough said.). That Scientific American printed such is totally discrediting to science.

17. Doubt is created about Darwin's ideas because of abortion and contraception. Indeed no culture really believes in Darwin when the culture has totally dropped out of "evolution" because of acceptance of totally antiDarwin abortion and contraception. Abortion and contraception create unnatural sexuality wherein "sex" is no longer as in nature: In nature, copulation is always between mature opposite sexed members of the same species at a time consistent with reproduction (rare biochemical errors exceptions).
Abortion and contraception convert human sexuality into a masturbatory epidemic (Read Kinsey, Crimes, and Consequences by Judith Reisman). The Kinsey and gay cult takeover human sexuality have denatured "sex" into penis-squirt and vagina-slime manias anytime, anywhere, any way, alone or with any one or any thing--It is all Kinsey's "sex outlet" living and an excretory function-sexcretionwhich is not really "sex" at all as sex is in nature. The resulting liberal culture of masturbation of today destroys natural productive male-female relationships; destroys the traditional family; and is totally antievolutionary and not positive natural selection normally understood. Instead, "sex" today is nothing more than the selfish loss of function of the human reproductive system incompatible with Darwinism as currently promoted. In fact, non-reproductive genital mania has redefined "gender" to be one's preferred way of masturbating rather than "male" and "female." And, by the way, "chronic loss of function" is the definition of "disease."

18. Doubt is created about Darwin's ideas because they are promoted more and more by a bunch of dirty old men and probably dirty old women (Proof of that may be their love for the assault-on-childhood book, It's Perfectly Normal by Robie Harris). They tend to be Alfred "pedophile" Kinsey sex-outlet-practicing atheists first. Atheism is their "religion" (make that pseudo-religion, because real religion requires belief in a Loving God)Naturally, they strategically deny they are "a religion" so their belief system can be promulgated by the state.

First, contemporary atheism is a form of animalnature worship with a demand for nihilism and expedient aggrandizement. Second, they are evolutionists meaning that evolution is their dogma (without metaphors of 
science but plenty of solipsistic philosophical arguments denied as such) defended like the Bible for Baptists. And third, they are pseudoscientists in methodology—to read their promotions of evolution is, for the most part, blatant hucksterism and an insult to science as they almost claim that Beethoven's music created itself. And they defend each other shamelessly-my demonstration of an undeniable lie and scientific fraud by Richard Dawkins has been ignored for years by the major press, Scientific American, and Oxford University (although I think Oxford discretely demoted him)-No one wants to discredit one of their topknots (Mother Theresa's fleeting doubts get full press coverage while scientific fraud by Richard Dawkins is ignored (Journalism has no ethics)).

For most, atheism is trying to prove a negative by simplified nihilism about incredible nature and supernature, obvious to all conscious-of-consciouness creatures trying to make sense of the universe, who conclude that there is more than this craziness on earth.

Basically and scientifically, the universe is the entropy necessary for Love capable creatures returning to the pre-Big Bang-pre-Universe Statimuum of a Loving God whose Love would naturally require the creation of creatures capable of returning back the Him. You cannot "earn" it but you can screw it up. You will get what you are: a creature trying to be Transcendent: truth, oneness, good and beauty, lived in Eternity by focusing on the Catholic Mass Mantra of: "Life, Sacrifice, Virtue, Love, Humanity, Peace, Freedom and Death without Fear"; or a creature in hell living over and over against oneself, one's own non-being anti-transcendent acts perpetrated on earth against Love now received back on oneself in Justice served. Atheists just do not want anyone telling them they are wrong about anything--like the Ten Commandments or any other "wake up, there is more" shouting.

I guess, the Big Bang is my alternative to evolution seeing it as kaleidoscopic explosion expansion of all the space/time continuum from the immediacy of all in the Eternity, better now called "the Statimuum" (from statim, the latin for "immediately") and into which some creatures will recompress--All this being a scientific theory of our universe in contemporary language.

Atheists are deluded in their know-it-all rejections of the intense profound ancient secrets. Atheists have not found contemporary reality metaphors which restate ancient metaphors in ancient languages. Atheists do not want to know or even hear about even scientific metaphors, because they feel unequal when someone seems to know more than they and dares to offer conscious-of-consciousness at a transcendent different level. "How dare the Church tell me what to do!" But the Church is telling you how best NOT to do evil (Evil is the creation of NON-BEING). Better (no EASIER) to believe you have proved a negative: "There is no God." Furthermore, the psychological basis for atheism is not Darwinism but the loss of significance of sexual reproduction (The Nazis knew and taught that unnatural sexuality reduced and removed people's religiosity and morality). If the sex act means nothing...if reproduction means nothing--then humanity is meaningless too and there is no need for love based behaviors and "anything goes" because "there is no spirit", just "power."

But dealing with atheists has made clear who and what they are, epitomized by their "anti-Christmas" war with BEING. Atheist, secularists, and satanists, the whole 
gang, are totally self-discredited as they loudly imitate the "evangelists" they reject, amazingly offering dogmas of universal subhuman materialist NON-SPIRITUALITY, as they offer "spirituality" time and time again, ignorantly unaware that they are doing so. Indeed, as self-defined, they cannot honestly even deal with the Catholic Mass Mantra (supra) or any other such spiritual human concepts including truth, oneness, good, and beauty or any thing else they cannot reduce to chemistry or physics.

On the internet, "Salon" and "Huffington Post" especially, and all in the atheist gang seem to be an obnoxious, self-righteous, juvenile, in-your-face puerile, "take that" primitive, mean, rude, un-intelligent, insulting, vulgar, angry, smart-alecky, not wanting truth seeking dialogue, unneighborly, un-historical, "evangelical"wannabes carrying on about all sorts of old antireligious ideas dealt with by the Church so many times in the past that the Church just does not want to bother with the flimsy non-neocortical "scholarship" of third graders having tantrums and dumbed and numbed by "evolution without scientific criticism" or by the erroneous belief that "evolution means Godless" or that any "meaning" to life beyond sex or power is fiction. The smirking willful OFFENDING of others is simple bigoted intolerance and unconscious jealousy. Atheists tend to be pitiful and flagrant COWARDS, not preaching to where most evil comes from so-called "religion": Muslims. Maybe atheists know that Muslims will treat them by something other than religious LOVE. Like: "Merry Loveolution" and "Happy Incarnation"--the physics of Christmas of which they do not want to understand....Atheists believe in the Big Bang, but not the pre-Big Bang or the pre-Universe.
Atheists tend to be scientific cronies and frauds, the numbers overwelming the National Academy of Science such that it closed its "fraud" division. Amazing. Atheists et al offer nothing; have excluded themselves from "spirit"; must offer the periodic table for every phenomenon; and cannot honestly use any metaphors to explain anything. But they keep using crude unrealistic metaphors to degrade the Church. Atheists need prayers and new metaphors.

The atheist gang should be referred to, on the WWWeb: "God and Nature-University of Notre Dame"; "Theogeocalculus"; and "Teilhard de Chardin". And my book: The Soul of the Earth....

In addition, not that Creationists must be fully believed, but not to feel delight and pleasure at the efforts of Creationists is a sign of closed minds, intolerance, lack of levity and a loss of full humanbeingness. See "Creation Science"

http://www.teachinghearts.org/dre09creationnotes.html.

They should have a little fun for a change and enjoy the weird curves of science and purely innocent believing amino acids. Darwinists need to relax and take comfort in their science and stop being racists, bigots, and against other people who think differently (Their prejudice and discrimination against believers is palpable).

Finally, Darwinists seem overwhelmed by the problem of evil and suffering to which I offer from my own www.theogeocalculus.com (which offers, I believe, the first ever linking of the basic principles of physics to the transcendentals, to the bases of psychotherapy and mental succor, to the sacraments, to the community universals and to the virtues): 
Suffering exists because of freedom. God's perfection gives freedom to choose, and

in that perfection the extremes of choosing from ultimate transcendental living to

ultimate non-being (evil) will occur, because the choices of freedom require a polarity

from God to satan (or simplistically, from good to bad). Therefore satan and evil

exist for $\mathrm{C}^{2} \mathrm{CC}$ (Conscious of Conscious Capable Creatures) who have freedom.

Such is the perfection of God. To be free, we have to choose, and the choices must

range from one extreme to the other or "choice" (and freedom) is meaningless. We

will suffer by pain and sin, but suffering has value because of the Incarnation and the

Crucifixion. Choosing Jesus overcomes it all.

Now that is what I call " metanatural selection" consistent with the metastability of elementary particles of physics. Read Soul of the Earth.

19. A scientific understanding of the planetary requirement for "life" as observed on earth render its duplication elsewhere to be impossible. The earth's atmosphere is $78 \%$ nitrogen , $21 \%$ oxygen, $1 \%$ argon; the earth is $70 \%$ covered with water miraculously stirred by a broken off chunk of the earth (the moon) rotating perfectly around the earth; the geomagnetism of the earth projects an amazing protective barrier against life destroying forces; the earth's temperature is overwhelmingly fixed above freezing and below boiling so life can exist; the rotation of the earth is amazingly stable on a 24 hour "barbecue spit" at another amazing perfect "warming" distance from the sun; the periodic table for the earth contains 118 elements from hydrogen with atomic weight of 1 to ununoctium with atomic weight of 294; 14 elements are essential for plants; 11 elements with 14 trace elements are essential for the human body for normal functioning; some elements, thankfully well secluded, are toxic to life; one can go on. To find another planet duplicating the earth with the periodic table in the right quantities begs belief.
CONCLUSION: My conclusion must begin with comments on The Blind Watchmaker: Why the evidence of evolution reveals a universe without design by Richard Dawkins. As gurus are usually intoxicated by success, Dawkins writes monomaniacally with arrogant compulsivity to reify mathematical hypothesizing with no evidence except his sketches to verify his pretensions. And his computing and sketching totally ignore the lefthandedness of most of all life's proteins also. But I will offer one quote from the book wherein Dawkins states, consistent with Darwin's “imaginary examples," his reason for using an artificially high rate of mutation in his sketches and calculations:

In real life, the probability that a gene will mutate is often less than one in a

million...and humans haven't the patience to wait a million generations

for a mutation! (page 57)

But we can figure what that means. For humans, with 30,000 genes, a 20 year generation and one in a million genes mutating, $6 \times 10^{11}$ (600 billion) years are needed to develop those genes. Or needed from "mitochondrial Eve" (about 150,000 years ago) are 5.33 positive mutations per year! That is just the genes. Of course, the process needs duplicating for each person's 10 trillion human cells, which are filled with trillions more subgenetic proteins, all errorlessly stably communicating by pathways of more trillions of fairly complex proteins all needing to be capable of instanteous perfect compliance with the changed gene new directions. Dawkins dismisses this as solved by "embryology," a word he uses for all the postgene protein linkages and the millions of protein pathways present and taken for granted by him in the unity of the 10 trillion cells of the human body. His wild goose chase with "cumulative accumulation," which cannot 
be confirmed for positive mutations, is woefully inadequate for the development of all the living beings, and not just humans. A better title for Dawkins book is: The Metaphor King: Why drawing lines is evolution (Furthermore, Dawkins is totally refuted and shown to be an academic fraud and professor imposter at Oxford University by Thomas Crean's book: God Is No Delusion, Ignatius Press, San Francisco, 2007-I stopped my critique at the title of Dawkins' book, The God Delusion, knowing he was fool and a fraud because he willfully used the word "delusion" when he admitted in the book itself that such was an academic and scientific prevarication. Crean's book goes further and takes Dawkins apart demonstrating his laughable scholarship.).

Darwin must be doubted because life's "ascent" is obvious rather than "descent." Life is a symphony of increasing anti-entropic complexity to spirit rather than universal warfare. From the Big Bang, no one has ever witnessed or documented the evolution of one genus from another. Instead, there is a "science of the gaps" with evolutionists leaping from one creature to another claiming a relationship when there is nothing more than common construction blocks at best. Furthermore, absolute general disproof of all Darwinism's cruel evolution with every man (creature) for himself is Western Civilization itself wherein people, against Darwin's ideas, work transcendentally together consistent with Nature's environmental symphony.

Regardless, the parroting of several biological vignettes of superficial similarity for a limited group of organisms cannot be grandiosely judged as applicable to all resulting in the alleged phylogenetic tree of life, even if done in 434 pages. Simplistic theories of common descent and natural selection are inept trivializations failing all but circumstantial evidence, if that. Genuine kindredness is not the same for all just because all creatures are composed of amino acids.

Life is really "survival of the transcendentally adaptable" -- all deriving from that punctate Big Bang Fire. All life is comprised of spin-offs of fire forms ever since. There is the red fire we know as blood. There is the orange fire we know as oranges. There is the yellow fire of the sun. The green fire of chlorophyll.The blue fire of water.The indole fire of insects.The violet fire of flowers.There are fire forms of truth, oneness, good andbeauty. And there is the ultimate fire form traceable back to the Big Bang very beginning, i.e., the fire form of love (Can you not feel its warmth?). Truly, we understand "life" and "love" as much as we understand "fire," so we can only take this trinity for granted. But life, love, and fire are not at war with each other as a Darwinian evolutionary process. There is a meaning to life, and it is not Darwinism which belongs to life's entropy known as "non-being, sin and suffering." And Darwin's evolution is absolutely inconsistent with Albert Einstein's “God does not play dice with the universe," (nor would God ever abandon, I would add, a creature made in His Image) said in response to the fine tuning necessarily accompanying the Big Bang Theory of Belgian priest-scientist Father LaMaitre. Somehow, only a Catholic priest, familiar with Life, Love and Fire (or, maybe Father, Son and Holy Spirit), could formulate the true linearity of existence and being. Perhaps more than Darwin, we should turn to Stanley L. Jaki (If you do not know his work, you are missing everything), another priest-scientist, but, regardless, let us always celebrate 
human achievements which make us think, even if just anecdotes not meeting decent standards of science.

One can only close these doubts about Charles Darwin by returning to the beginning and his notes during the famous voyage of the HMS Beagle on the natives of Tierra del Fuego:

Viewing such men, one can hardly make oneself believe that they

are fellow-creatures, and inhabitants of the same world. It is a

common subject of conjecture what pleasures in life some of the lower

animals can enjoy: how much more reasonably the same question may

be asked with respect to these barbarians! At night, five or six human

beings, naked and scarcely protected from the wind and rain of this

tempestuous climate, sleep on the wet ground coiled up like animals...

....The different tribes when at war are cannibals...it is certainly true,

that when pressed in the winter by hunger, they kill and devour their

old women before they kill their dogs....

....Was a more horrid deed ever perpetrated, than that witnessed on

the west coast by [Admiral] Byron, who saw a wretched mother pick

up her bleeding dying infant-boy, whom her husband had mercilessly

dashed on the stones for dropping a basket of sea-eggs!... most important

....the voyage of the Beagle has been by far the

event in my life...the sight of a naked savage in his native land is an

event which can never be forgotten.

Now we know where Darwin got his special spiritual outsight which transformed him into an exemplary guru. And he puts it all into effect, calling it "evolution" —as in the title of his seminal work: "...Natural Selection or the Preservation of Favoured Races" (Whenever you hear "natural selection" think of what Darwin meant-I think "Evobabble" would have been a better title for his book.). The unfit animals, which now includes a lot of us, are able to be named and, because we are evolved, justifiably targeted. So Darwin (if you cannot beat 'em, join 'em?), without realizing, does intellectually what he saw done materially by the natives, bringing us back to a primitive anti-life, unloving, cold irreligious war with all. And the only tangible thing evolution has really given the world are gurus of metaspeciation who dehumanize their own species in the process.

Actually, all Darwinism reminds of my beloved Aunt Rose's frequent exhortation to me as child not to be suggestible or to imitate every thing I saw: "Monkey see, monkey do...and you are not a monkey! So do not do everything you see! Or believe everything you hear! You are not a monkey! Monkey see, monkey do!” That advice served me well for over 70 years. Darwin needed an Aunt Rose. So do Darwinists.

So let the sophomoric throwing of sticks and stones begin or better yet read Origin of the Human Species by Dennis Bonnette or best yet go to Mass for a touch of the Statimuum. 